\title{
Relação entre a geodiversidade intrínseca e a estruturação de habitat na es- cala do geossítio: exemplos na Serra do Segredo e nas Pedras das Guaritas (Caçapava do Sul, RS, Brasil)
}

\author{
André Weissheimer de BORBA ${ }^{1}$, Elisângela Lopes da SILVA ${ }^{1}$, Luiz Paulo Martins e SOUZAํㅜ, Luiz \\ Fernando de SOUZA² \& Rosane Vera MARQUES ${ }^{2}$
}

(1) Grupo de Pesquisa PANGEA (Patrimônio Natural, Geoconservação e Gestão da Água), Programa de Pós-graduação em Geografia, Universidade Federal de Santa Maria, Av. Roraima, 1000, Camobi, CEP 97.105-900, Santa Maria, RS, Brasil. E-mail: awborba.geo@gmail.com, tikita.lopes@gmail.com, martinsesouza@gmail.com.

(2) Ministério Público do Estado do Rio Grande do Sul. Rua Gen. Andrade Neves, 106, 10 Andar, Centro, CEP 90.010-210, Porto Alegre, RS, Brasil. E-mail: luizfsouza@mprs.mp.br, rvmarques@mprs.mp.br.

Recebido em 08/2015. Aceito para publicação em 04/2016.

Versão online publicada em 31/05/2016 (www.pesquisasemgeociencias.ufrgs.br)

\begin{abstract}
Resumo- Os geossítios são locais ou áreas que melhor representam a geodiversidade de um território, ou seja, a variedade natural de elementos geológicos. Entre os critérios de avaliação quantitativa de geossítios está sua importância na estruturação de habitat, relacionado a seu valor funcional ou de suporte ecológico. Este trabalho objetiva apresentar as relações entre a geodiversidade intrínseca (de feições geológicas) de um geossítio e a diversidade de habitat e/ou abrigos existentes. Para isso, analisaram-se informações da bibliografia, imagens de satélite, fotografias aéreas e dados provenientes de saídas a campo em diferentes épocas do ano nos geossítios Serra do Segredo e Pedras das Guaritas, ambos no município de Caçapava do Sul, centro-sul do Rio Grande do Sul. Demonstra-se aqui a importância de feições deposicionais, deformacionais e intempéricas, na escala do geossítio, para a estruturação e a manutenção de diversos tipos de ambientes e organismos: de líquenes a fragmentos florestais, de formas jovens de anfíbios a mamíferos de médio porte.

Palavras-chave: geoconservação, geopatrimônio, ecologia
\end{abstract}

\begin{abstract}
RELATIONSHIP BETWEEN INTRINSIC GEODIVERSITY AND HABITAT STRUCTURING AT THE GEOSITE SCALE: EXAMPLES IN THE GEOSITES SERRA Do SEgREdo AND PEDRAS DAS GuARITAS (CAÇAPAVA do SUL, RS, BRAZIL). Geosites are points or areas that represent better the geodiversity of a territory, i.e. its natural range of geological elements. Among the criteria used for the quantitative assessment of geosites is its relevance for structuring habitat, related with its functional or ecological support value. This paper aims at presenting the relationships between the intrinsic geodiversity of a geosite (its geological features) and the existing habitat diversity. Thus, the geosites Serra do Segredo and Pedras das Guaritas, both located in Caçapava do Sul, south-central Rio Grande do Sul State, were analyzed in detail. Literature review, satellite and aerial photograph images were analyzed, as well as data collected during fieldtrips in different seasons. It is highlighted here the importance of depositional, tectonic and weathering features, at the geosite scale, for the structuring and maintaining various types of environments and organisms: from lichens to forest fragments, from amphibian tadpoles to medium-sized mammals.
\end{abstract}

Keywords: geoconservation, geoheritage, ecology

\section{Introdução}

0 conceito de geodiversidade, no âmbito das geociências, é relativamente recente, tendo sido introduzido por Sharples (1993) como uma analogia ao termo biodiversidade, para sustentar que a natureza é o somatório indissociável de elementos bióticos e abióticos. Demonstrando, desde suas primeiras conceituações, essa associação de dependência mútua, Stanley (2000) define geodi- versidade como "a variedade de ambientes, fenômenos e processos geológicos que produzem paisagens, rochas, minerais, solos e outros depósitos superficiais formadores do arcabouço que sustenta a vida na Terra". Na mesma linha, Gray (2004) conceitua geodiversidade como "a diversidade de feições ou elementos geológicos, geomorfológicos e de solo (...)", dando maior ênfase aos produtos da evolução terrestre. Uma abordagem diferente é trazida por Panizza (2009), que vê duas dimensões 
da geodiversidade: (1) a geodiversidade extrínseca, um conjunto de características que torna um elemento geológico/geomorfológico realmente singular em relação a outros de mesmo contexto; e, (2) a geodiversidade intrínseca, a variedade de feições que um local ou área apresenta em seu interior (ver revisão de conceitos em Borba, 2011).

Os locais que melhor representam a geodiversidade e a evolução geológica de um determinado território, sobretudo do ponto de vista científico, são chamados de "locais de interesse geológico" (García-Cortés \& Carcavilla-Urquí, 2009) ou, simplesmente, "geossítios" (Brilha, 2005, 2015). Esses locais podem ser afloramentos pontuais, seções, miradores, áreas simples e grandes áreas complexas (Fuertes-Gutiérrez \& Fernández-Martínez, 2010). O conjunto desses geossítios, somados a elementos que tenham sido extraídos de seu local original (mas que preservem seu valor geocientífico, em museus, por exemplo), constitui o geopatrimônio daquele território (Borba, 2011; Brilha, 2015). Entre os principais critérios para avaliação quali-quantitativa de geossítios, está a sua importância ecológica, ou seja, o quanto aquela feição da geodiversidade é importante para a estruturação ou manutenção de habitat ou de espécies endêmicas, raras ou ameaçadas (e.g. Fassoulas et al., 2012; Borba et al., 2013). Esse parâmetro está intimamente relacionado com o valor funcional (Gray, 2004; Brilha, 2005) ou de suporte a habitat (Gordon \& Barron, 2013) que os diferentes elementos da geodiversidade desempenham. Diversos estudos demonstram uma significativa correlação entre índices de geodiversidade e de biodiversidade (e.g. Jacková \& Romportl, 2008; Fragoso-Servón et al., 2014; Mohammad \& Al-Zubaidi, 2014), mas quase sempre utilizam ferramentas de geoprocessamento e escalas de grande abrangência. Isso implica a perda de detalhes que só poderiam ser percebidos na escala do geossítio e mediante a observação direta, em campo.

As áreas da Serra do Segredo e das Pedras das Guaritas, situadas no município de Caçapava do Sul (centro-sul do Rio Grande do Sul, na região das Serras do Sudeste, possuem cada uma cerca de $30 \mathrm{~km}^{2}$ e podem ser classificadas, no esquema proposto por Fuertes-Gutiérrez \& Fernández-Martínez (2010), como grandes áreas complexas. Compõem-se de cerros ruiniformes desenhados sobre arenitos e conglomerados fluviais da transição Neoproterozoico/Paleozoico (Borba, 2006; Paim et al., 2010; Borba et al., 2013). Essas duas áreas compreendem as ocorrências do geopatrimônio mais bem avaliadas do estudo realizado por Borba et al. (2013) para toda a extensão territorial do município, resultando em altos valores educativo e turístico. Esse resultado deve-se a uma série de fatores, entre eles: (a) sua representatividade em termos de processos geológico-geomorfológicos; (b) seu destaque na paisagem e beleza cênica; (c) a substancial geodiversidade intrínseca de ambos os geossítios; e, (d) sua importância na estruturação de habitat. 0 objetivo deste trabalho, que se baseia em observações qualitativas de campo e em imagens de satélite, é demonstrar, por meio de exemplos concretos observados e documentados nos geossítios Serra do Segredo e Pedras das Guaritas, o quanto a geodiversidade intrínseca de um elemento do geopatrimônio pode ser decisiva para a estruturação e a manutenção de habitat, bem como de espécies raras, endêmicas e/ou ameaçadas de extinção. Ao mesmo tempo, pretende-se reforçar a necessidade de se considerarem os elementos da geodiversidade, especialmente as formas de relevo, em estratégias de conservação da natureza e no planejamento de unidades de conservação (UC).

\section{2 Área, materiais e métodos}

\subsection{Evolução geológica da Serra do Segredo e das Pedras das Guaritas}

Os geossítios Serra do Segredo $\left(30^{\circ} 32^{\prime} 06^{\prime \prime} S\right.$, 533' $12^{\prime \prime} \mathrm{W}$, figs. 1, 2A) e Pedras das Guaritas (30 $30^{\prime} 08^{\prime \prime}$ S, 5330'09”'W, figs. 1, 2B) são formados por rochas sedimentares continentais, de coloração avermelhada, vinculadas às formações Santa Bárbara e Guaritas, da chamada "Bacia do Camaquã” (Paim et al., 2000; Borba, 2006). Não há consenso, entre os pesquisadores, sobre a posição estratigráfica relativa entre as duas unidades, havendo sugestões tanto no sentido de sua contemporaneidade (e.g. Borba, 2006) quanto no sentido de haver uma discordância angular entre elas, com a unidade Guaritas sendo mais jovem (Paim et al., 2000). Tais relações não constituem assunto pertinente aos objetivos deste trabalho, que focaliza o que há de consensual em termos de evolução geológica. 0 que importa salientar aqui é o fato de que a "Bacia do Camaquã", especialmente nas ocorrências e unidades estratigráficas citadas, constitui o mais completo e bem preservado registro do chamado "estágio de transição" entre as faixas móveis da orogenia Brasiliana e a fase estável da Plataforma Sul-americana (Almeida, 1969), o que atesta seu inegável e singular valor científico.

As rochas que constituem o substrato da Serra do Segredo pertencem à seção mais jovem da Formação Santa Bárbara, a qual possui cerca de 


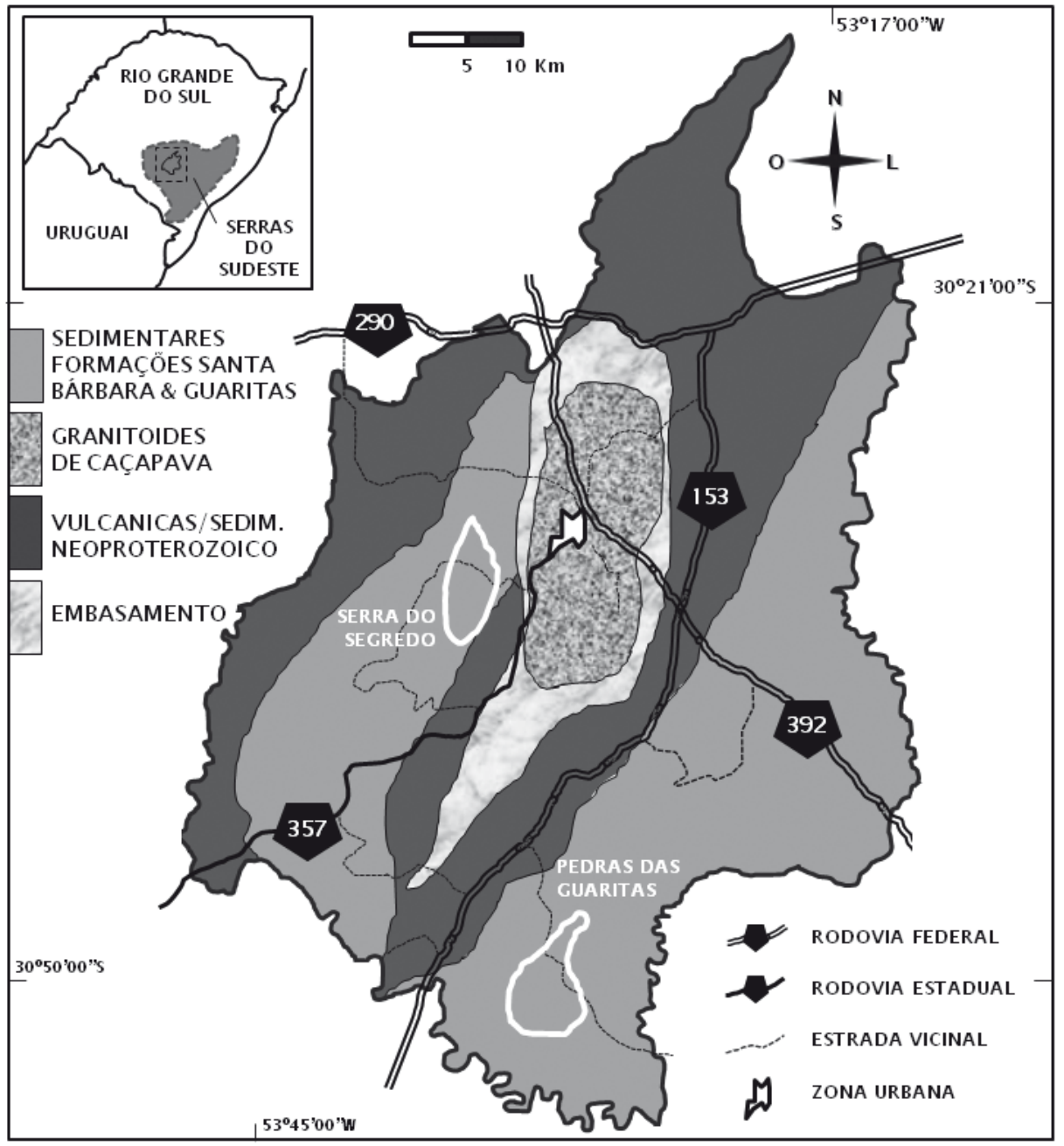

Figura 1. Mapa geológico esquemático do município de Caçapava do Sul (adaptado de Borba et al., 2013), com seus quatro grandes contextos geológicos e a localização dos dois geossítios focalizados neste trabalho: a Serra do Segredo e as Pedras das Guaritas (áreas com contorno branco sobre o mapa).

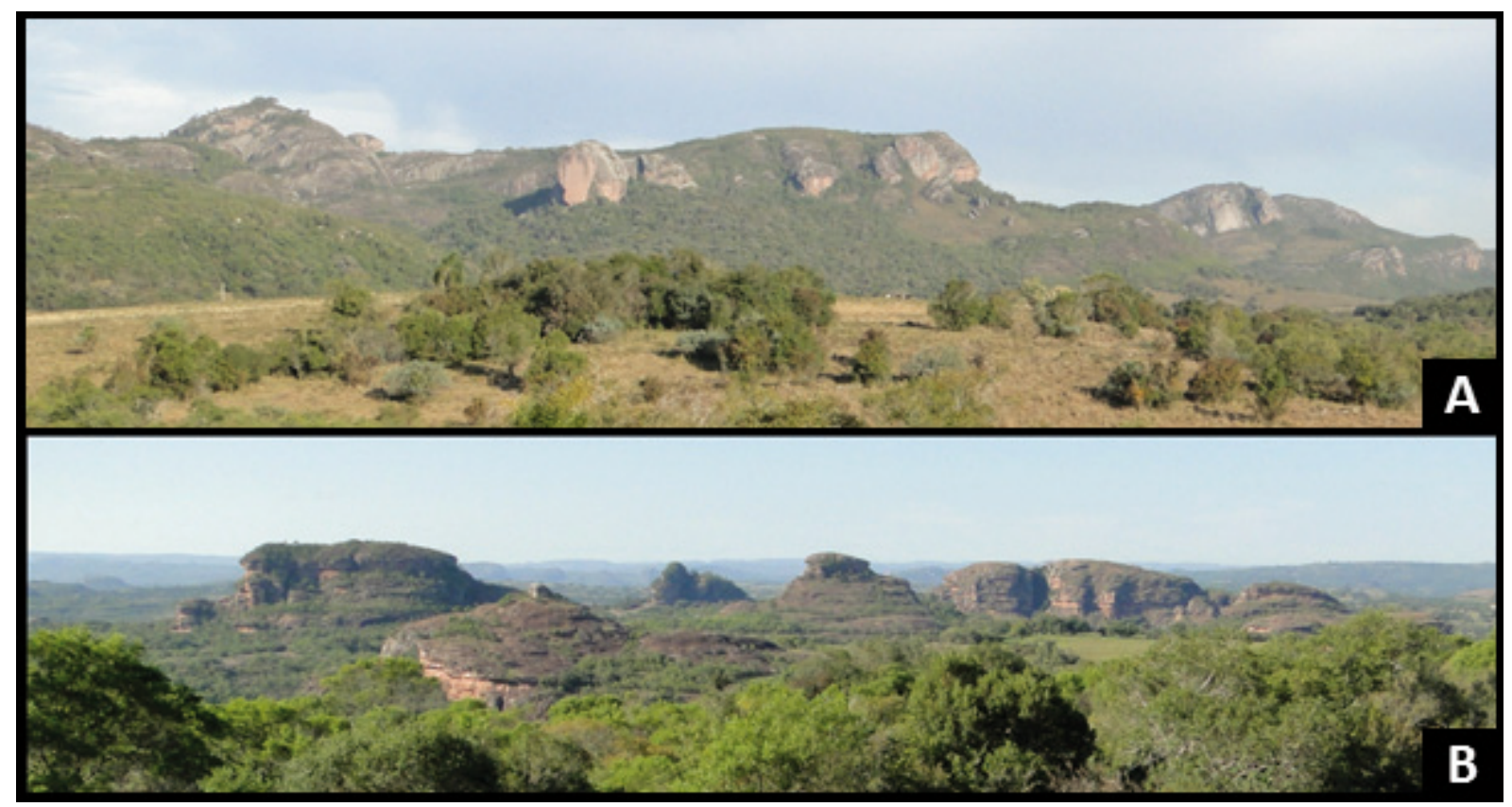

Figura 2. Vistas panorâmicas das paisagens (A) da Serra do Segredo e (B) das Pedras das Guaritas, áreas de grande destaque na paisagem e singular beleza cênica. 
$300 \mathrm{~m}$ de espessura. Dominam os arenitos conglomeráticos e conglomerados (Fig. 3A), dispostos em camadas de geometria lenticular e em forma de escavação (scoop-shaped), com estratificações cruzadas acanaladas (Borba \& Mizusaki, 2003). Subordinadamente, ocorrem camadas de geometria lenticular ou tabular de conglomerados sustentados pelos clastos (Fig. 3B), maciços ou com estratificação horizontal. Essa associação de fácies reflete a ação de dunas subaquosas de crista curva, em um sistema fluvial entrelaçado com carga arenosa e cascalhosa, que recebia a contribuição lateral de leques aluviais provenientes de montanhas adjacentes. Os fragmentos dos conglomerados e da fração conglomerática em arenitos, em sua maioria do tamanho bloco, indicam fontes vulcânicas (riolitos, andesitos) relativamente distantes e a contribuição mais proximal de rochas metamórficas (xistos básicos, anfibolitos) e dos granitoides de Caçapava do Sul (Borba et al., 2002; Borba, 2006). As rochas sedimentares da Serra do Segredo possuem empacotamento apertado, sendo muito litificadas e tendo como principal cimento a calcita e os óxidos de ferro, o que reforça seu caráter continental, com deposição em ambiente oxidante. Dados de termocronologia traços de fissão em apatita (TFA) demonstram que as temperaturas de diagênese alcançadas pela seção superior da Formação Santa Bárbara ultrapassaram os $120^{\circ} \mathrm{C}$ durante um período de tempo significativo (Borba, 2001). A substancial litificação empresta às rochas uma considerável resistência ao desgaste físico, em nada lembrando o caráter geralmente friável da maioria das rochas sedimentares.
Após sua formação e diagênese relativamente profunda, as rochas da Serra do Segredo foram afetadas por falhas e fraturas (Fig. 4A), especialmente na direção NW-SE, que parecem ter um importante papel na tectônica de blocos e no seu soerguimento diferencial (Borba et al., 2003; Borba, 2006). Essas falhas podem estar associadas aos períodos Permiano e Triássico, com reativações ao longo do Cretáceo (Borba et al., 2002). Quanto à sua evolução geomorfológica, não há estudos técnico-científicos de detalhe, mas podem ser citadas algumas características relevantes: (a) a disposição em cerros com formas arredondadas, com paredões retilíneos na direção NW-SE (Fig. 4B); (b) a presença de cavidades do tipo tafoni, especialmente nas faces voltadas para oeste, sendo algumas isoladas, como janelas, e outras amalgamadas, formando "degraus" nos cerros (Fig. 4C); e (c) a presença de feições do tipo "alteração alveolar" ou "honeycomb" (favo de mel) em paredes mais úmidas, dentro de cavidades voltadas para o sul (Fig. 4D). Essas feições teriam sido formadas ao longo das flutuações climáticas dos últimos 500 mil anos, quando climas quentes/úmidos se alternavam com períodos mais frios/secos (e.g. Suertegaray \& Silva, 2009). As feições de intemperismo observadas na Serra do Segredo são compatíveis com aquelas descritas por Mustoe (1982), Rodríguez-Navarro et al. (1999), McBride \& Picard (2000) e por Paradise (2013), nas quais os fatores preponderantes seriam a dissolução e recristalização de soluções salinas (no caso dos trabalhos citados, de calcita ou sílica) e, adicionalmente, a ação do vento na retirada (erosão) dos produtos desse intemperismo.

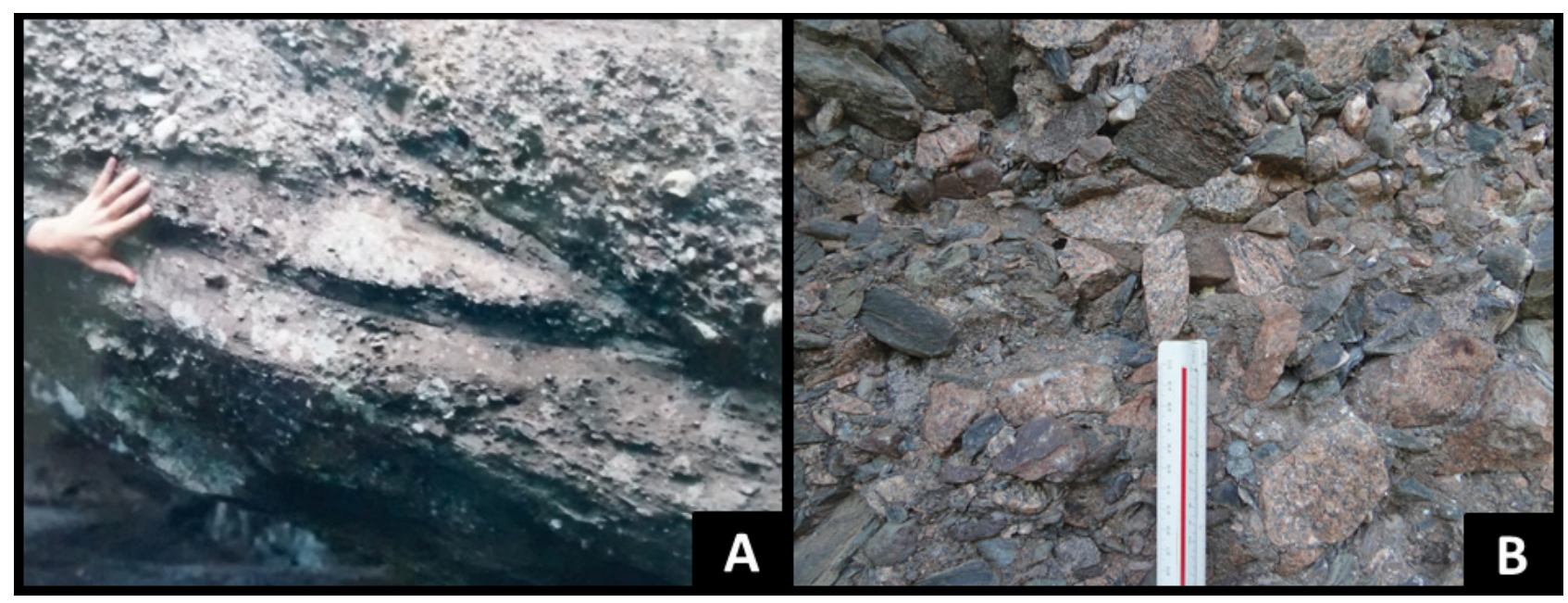

Figura 3. Aspectos das rochas constituintes do substrato da Serra do Segredo. A) Camadas lenticulares, em forma de escavação (scoop-shaped), de arenitos conglomeráticos e conglomerados; B) Conglomerados sustentados por fragmentos (no tamanho bloco) de rochas metavulcânicas e granitoides. 


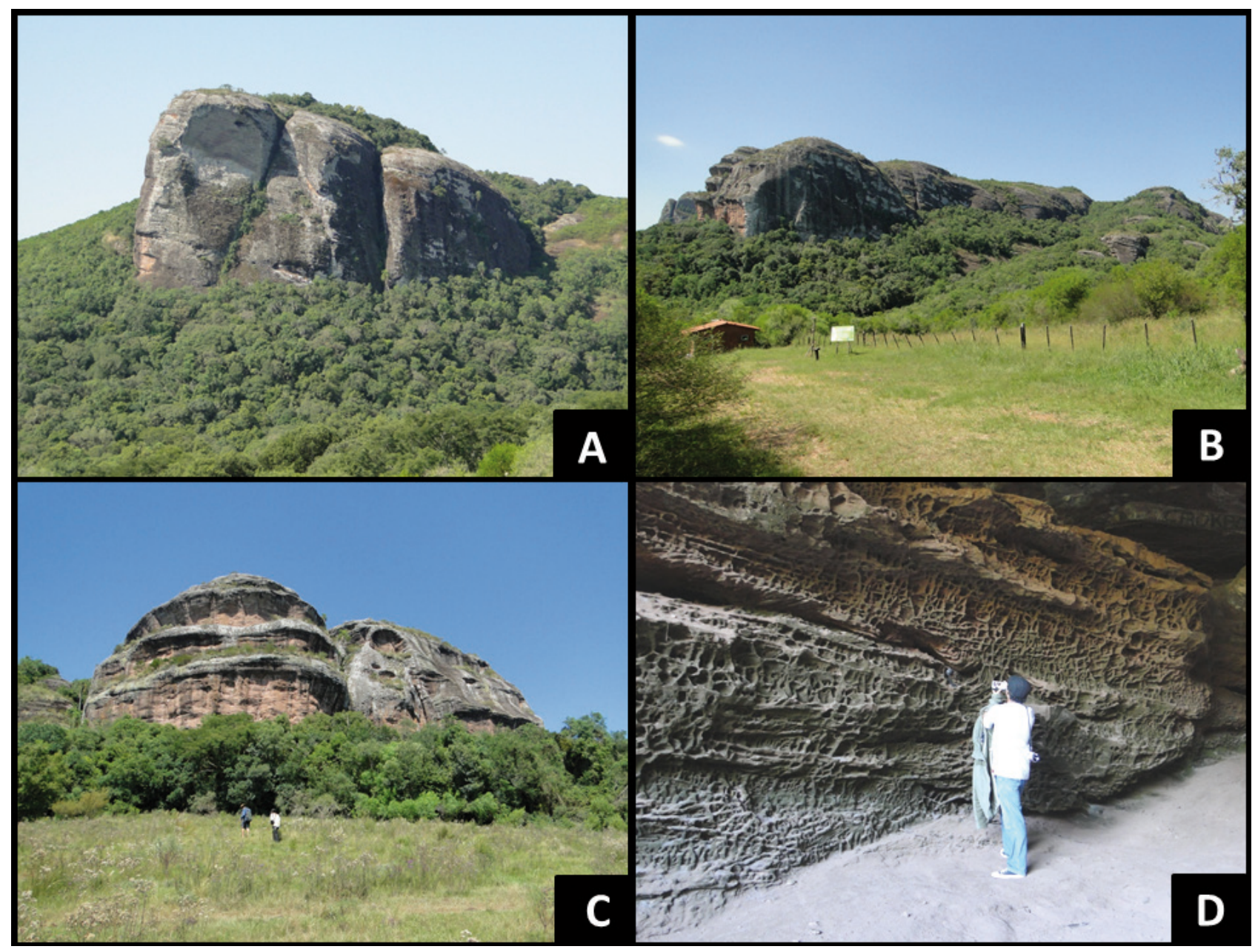

Figura 4. Feições do relevo da Serra do Segredo. A) Fraturas subverticais na geoforma "Pedra do Índio"; B) Formas arredondadas e degraus da geoforma "Pedra do Segredo", alongada na direção N60W; C) Face oeste da "Pedra do Segredo", com seus degraus e cavidades tipo tafoni; D) Feições do tipo honeycomb ou alveolares, na parede interna de uma das cavidades da "Pedra do Segredo".

Por sua vez, as rochas que compõem o geossítio Pedras das Guaritas são arenitos, arenitos com linhas de seixos e blocos, arenitos conglomeráticos e raros conglomerados, dispostos em camadas de geometria tabular ou lenticular de grande relação comprimento/espessura, com estratificações cruzadas planares e acanaladas (Figs. 5A, 5B). Essas camadas intercalam-se com arenitos finos a siltitos, e por vezes com arenitos bimodais com estratos de grande porte. Tais características compõem um sistema fluvial entrelaçado, mas de planície fluvial mais ampla, com menor energia e carga arenosa, mais fina, e talvez com áreas inundáveis, em um ambiente associado a dunas eólicas e a lagos efêmeros (Paim et al., 2000): um dos primeiros desertos do (então recém-formado) continente Gondwana. Paleocorrentes indicam que o sistema fluvial axial carregava os sedimentos no sentido do quadrante sul (SSW). A composição dos clastos tamanho bloco, muito bem arredondados, contempla granitos diversos (Fig. 5C), incluindo termos peraluminosos (Borba et al., 2003). As características de diagênese apontam algumas camadas com pouca compactação e muita cimentação (por calcita, sílica, óxidos e argilominerais), enquanto outras camadas são mais compactadas e menos cimentadas (De Ros et al., 1994).

As Pedras das Guaritas constituem um conjunto de cerros ruiniformes, de formatos diversos e irregulares (Fig. 2B), em que o desgaste físico e químico afetou de maneira diferencial as rochas de distintas granulometria e compactação (Paim et al., 2010). Os cerros mais destacados são capeados por camadas de arenitos conglomeráticos mais grossos, e até mesmo alguns conglomerados, camadas que ofereceram maior resistência ao intemperismo. Esse desgaste químico seletivo, seguido de erosão eólica, gerou feições do tipo tafoni, sobretudo nas faces verticais voltadas para norte e noroeste (Fig. 6A). Marmitas ou panelas (chamadas, na literatura internacional, de weathering pits, weathering pans ou gnammas, de acordo com Paradise, 2013) alinhadas segundo o fluxo da água também são muito comuns, especialmente na região das nascentes do arroio Passo dos Negros (Fig. 6B), no terreno da Associação de Moradores 


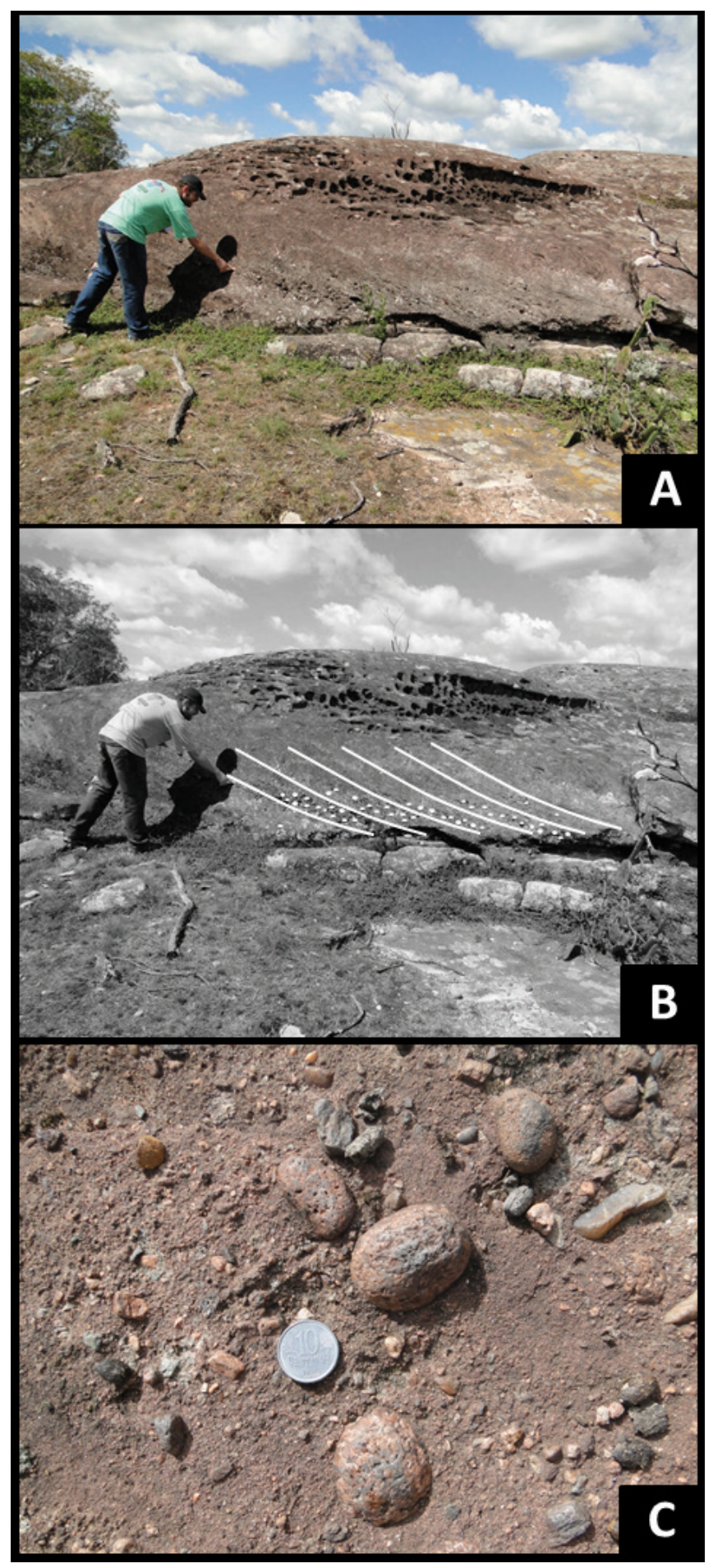

Figura 5. Rochas do geossítio Pedras das Guaritas. A) Camada de arenitos conglomeráticos com estratificação cruzada acanalada; B) Interpretação das estratificações cruzadas (linhas brancas contínuas) e das porções conglomeráticas (concentrações de elipses) sobre a fotografia A; C) Blocos muito arredondados de granitoides em meio ao arcabouço formado por arenitos grossos.

das Guaritas (Souza, 2014). Essas feições têm sua gênese provavelmente ligada ao desgaste preferencial (químico e físico), pela ação da água e da umidade, da matriz arenosa das rochas em torno de fragmentos arredondados tamanho bloco. 0 progressivo aprofundamento dessas marmitas possivelmente tenha utilizado, também, os próprios fragmentos maiores (de granitos diversos, riolitos e quartzo de falha, principalmente) como elementos abrasivos, conforme atesta a presença de numerosos blocos arredondados dentro das marmitas de maior diâmetro e profundidade (Fig. 6C). Registram-se, também, na área do geossítio Pedras das Guaritas, numerosos planos de falhas e fraturas, orientadas segundo as direções NE-SW e, principalmente, NW-SE, nessa última direção com espaçamento muito menor entre as estruturas do que, por exemplo, na Serra do Segredo. 


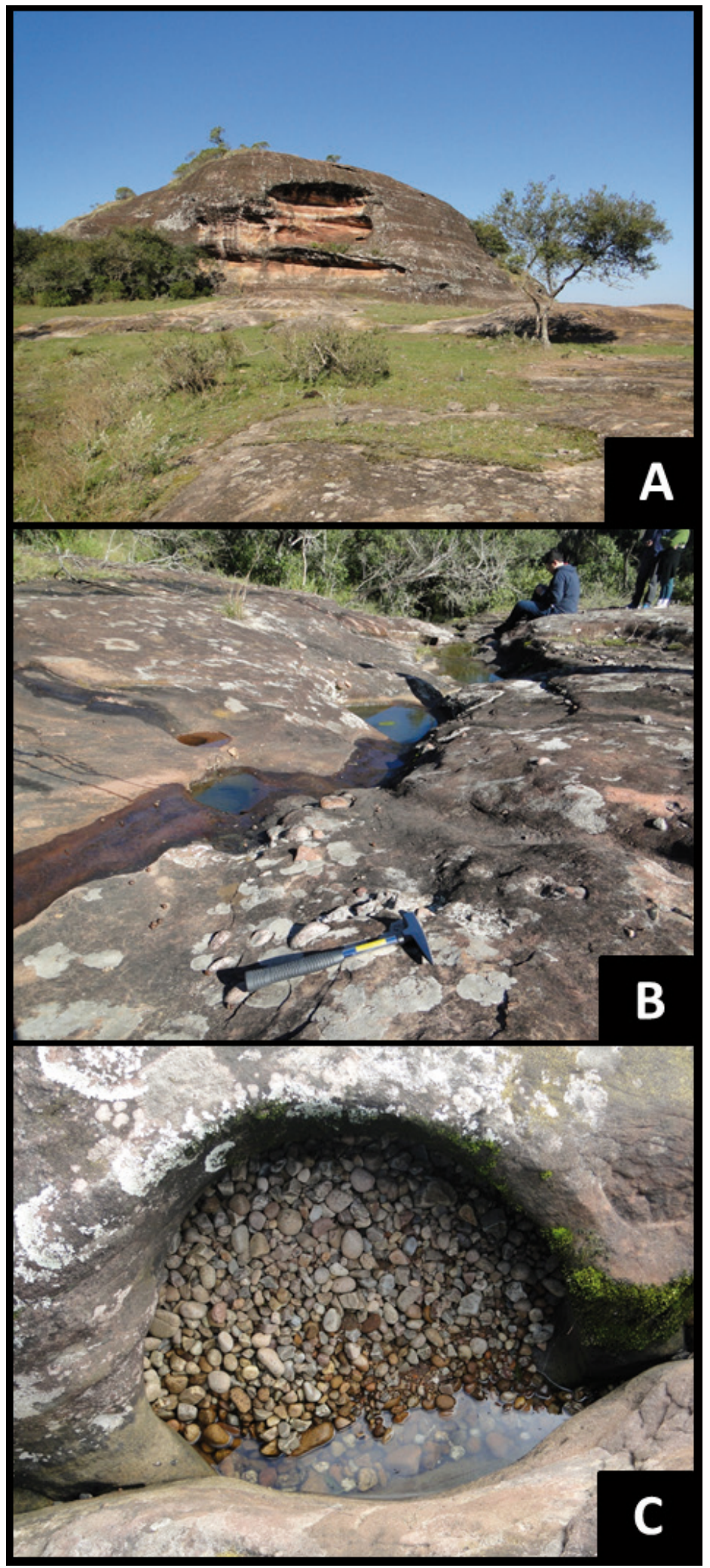

Figura 6. Aspectos geomorfológicos das Pedras das Guaritas. A) Face noroeste de uma das geoformas do geossítio, com feições do tipo tafoni; B) Concentração de marmitas (weathering pits, pans) alinhadas segundo o fluxo da água na região de nascentes do arroio Passo dos Negros; C) Marmita de cerca de $50 \mathrm{~cm}$ de diâmetro, com leito preenchido por grande quantidade de blocos arredondados de granitoides e quartzo de falha. 


\subsection{Flora e fauna: biodiversidade e endemismos nas áreas estudadas}

As áreas adjacentes aos geossítios Serra do Segredo e Pedras das Guaritas, assim como grande parte do município de Caçapava do Sul e de toda a área de abrangência do Escudo Sul-rio-grandense, são caracterizadas por formações vegetais campestres e do tipo savana-parque (Guadagnin et al., 2000), com um estrato herbáceo contínuo formado por gramíneas e também árvores espalhadas ou agrupadas, contando ainda com florestas de galeria. Em meio a esse ambiente, destacam-se os cerros de rocha nua, os quais abrigam uma série de habitat muito diferenciados. Conforme apontado já por Guadagnin et al. (2000, p. 79), realizado em parte da área das Pedras das Guaritas, "os afloramentos de rocha constituem-se nos habitat mais importantes do ponto de vista da preservação da flora ameaçada". Aqueles autores citam como ameaçadas de extinção as espécies vegetais Parodia crassigiba, $P$. ottonis, $P$. scopa, $P$. neohorstii e Frailea spp. (Cactaceae), assim como Petunia exserta (Solanaceae). Para a fauna, Konrad \& Paloski (2000) citam como relevante a presença remanescente do felino puma ou leão-baio (Puma concolor) e do tamanduá-mirim (Tamandua tetradactyla, Myrmecophagidae), além de aves, como o tucano-do-bico-verde (Ramphastos dicolorus). Já na área da Serra do Segredo (Projeto RS Biodiversidade, 2014), entre os organismos mais representativos, estão as espécies vegetais endêmicas Pavonia secreta (Malvaceae), Petunia secreta (Solanaceae) e Parodia rudibuenekeri (Cactaceae). 0 mesmo documento aponta significativa diversidade de anfíbios, répteis, mamíferos terrestres, morcegos e aves, destacando-se os mamíferos veado-virá ( $M a$ zama guazoubira, Cervidae) e cutia (Dasyprocta azarae, Dasyproctidae).

\subsection{Materiais e métodos}

A presente pesquisa iniciou-se a partir de uma abrangente revisão bibliográfica sobre as características de geologia, sedimentologia, tectônica, geomorfologia e ecologia dos geossítios Serra do Segredo e Pedras das Guaritas. Imagens de satélite disponibilizadas pelo sítio/software GoogleEarthPro®, bem como fotografias aéreas das áreas estudadas, foram utilizadas para inferir relações gerais entre geomorfologia, tectônica e vegetação. Da mesma forma, tais imagens foram importantes para o planejamento das saídas a campo em Caçapava do Sul. Focalizando os objetivos específicos desta pesquisa, foram realizadas três saídas a campo (em setembro de 2014, agosto e novembro de 2015) no geossítio Pedras das Guaritas, e outras cinco atividades de campo (em outubro de 2014, e em diferentes datas dos meses de março e outubro de 2015) no geossítio Serra do Segredo. Nessas oportunidades, em caminhamentos ao longo dos geossítios, as feições geológicas, tectônicas e geomorfológicas relevantes para a estruturação de habitat foram descritas e fotografadas, registrando-se as espécies vegetais e animais localizadas em planilhas de campo. Informações, dados e registros fotográficos obtidos em datas anteriores a essas atividades de campo também foram consideradas para os fins deste trabalho. Finalmente, as informações foram compiladas e interpretadas conforme os resultados e discussões abaixo.

\section{Resultados e discussão}

Conforme detalhado acima, as áreas da Serra do Segredo e das Pedras das Guaritas são o resultado de uma longa e complexa evolução geológica e geomorfológica, desde a gênese das rochas, passando por sua deformação rúptil, e chegando ao desenho das atuais formas de relevo e feições de alteração associadas. Esse conjunto de processos foi responsável pela formação de uma substancial geodiversidade intrínseca, ou seja, uma grande variedade de feições internas aos geossítios, as quais auxiliam a decifrar, compreender e divulgar sua evolução geológica. Essas feições são: (a) deposicionais, quando refletem as condições da sedimentação, como estratificações cruzadas, linhas de blocos arredondados ou camadas conglomeráticas; (b) deformacionais, quando atestam a ocorrência de processos de tectônica rúptil, como fraturas, falhas e basculamento (inclinação) dos pacotes de rocha; e (c) intempéricas, quando refletem o desgaste físico, químico e biológico sofrido pelas rochas na interação com a atmosfera, com consequente produção das geoformas e dos diferentes tipos de cavidades ali expostas. Essa geodiversidade intrínseca de ambos os geossítios favoreceu, de diferentes maneiras, a estruturação e a manutenção de habitat e os refúgios necessários para uma série de espécies nativas da flora e da fauna. A seguir, apresentam-se alguns exemplos dessa relação.

\subsection{Lineamentos tectônicos e formações florestais}

Os dois geossítios analisados neste trabalho, assim como toda a região centro-sul do Rio Grande do Sul, foram fortemente afetados por tectônica rúptil durante o Fanerozoico (e.g. Borba et al., 
2003), levando ao desenvolvimento de falhas e fraturas em diferentes direções (Figs. 7A, 8A). Conforme pode ser verificado já através das imagens de sensoriamento remoto, há um visível controle dos lineamentos tectônicos (marcados com linhas brancas) sobre a vegetação, fato que também se observa no campo. No geossítio das Pedras das Guaritas, os lineamentos orientados nas direções $\mathrm{N} 20^{\circ} \mathrm{E}, \mathrm{N} 30^{\circ} \mathrm{E}$ e $\mathrm{N} 70^{\circ} \mathrm{E}$ são, em geral, espaçados por centenas de metros de distância, e marcam a presença de uma vegetação arbustiva mais densa, quando comparada à matriz campestre do entorno. Outro conjunto expressivo de lineamentos orienta-se na direção $\mathrm{N} 20^{\circ} \mathrm{W}$, sendo essas estruturas separadas por distâncias menores, da ordem das dezenas de metros (Fig. 7A). Esses dois conjuntos de estruturas foram essenciais para a evolução geomorfológica do geossítio, resultando na configuração dos cerros ruiniformes que dão nome à região. Mesmo nas geoformas menos vegetadas daquele geossítio, formações arbustivas e até pequenas florestas lineares aparecem quando esses cerros são cortados por falhas ou fraturas de direção N20W (Fig. 7B). A vegetação é, igualmente, mais densa na face sul/sudoeste dos cerros orientados a noroeste, que recebem menor insolação. Nessas formações vegetais, dominam espécies como o chá-de-bugre (Casearia sylvestris) e o chal-chal (Allophylus edulis) e, segundo Guadagnin et al. (2000), merece atenção a ocorrência da coronilha-folha-de-buxo (Condalia buxifolia). Em um estudo realizado na região do Alto Camaquã, que inclui a área das Pedras das Guaritas, foram avaliados parâmetros relacionados à diversidade das espécies vegetais lenhosas (Dadalt, 2010). Foi demonstrado que as variáveis ambientais, as quais incluem variáveis climáticas, topográficas e edáficas, explicavam $28,4 \%$ da variação das espécies vegetais lenhosas, sendo mais importante que a distância geográfica. Além disso, o mapeamento de habitat para as espécies lenhosas a partir da análise multivariada dos parâmetros estudados indicava forte correlação com as feições do relevo.

No geossítio Serra do Segredo, a principal direção de lineamentos tectônicos é aproximadamente $\mathrm{N} 60^{\circ} \mathrm{W}$, o que faz com que os cerros de rocha impermeável, resistentes ao intemperismo, estejam também orientados nessa direção (Fig. 8A). As distâncias entre os lineamentos mais expressivos, os quais permitiram a ação do intemperismo químico, estão entre 150 e 300 m, sendo essa a largura aproximada dos cerros de rocha nua. Nessas geoformas, as porções de topo recebem forte insolação, sendo ocupadas apenas por líquenes, cactáceas e bromeliáceas como a Dickia sp., e utilizadas pelos répteis como substrato para o controle ectotérmico de sua temperatura corporal. Enquanto isso, as faces voltadas para sul e os vales encaixados recebem a menor insolação, especialmente no inverno, e por isso apresentam os maiores níveis de sombreamento e umidade. Ao mesmo tempo, nos vales e faces sul, as estruturas e o intemperismo favoreceram a formação de solos mais profundos e férteis. Essa condição, ditada pela resistência dos cerros ao intemperismo, pela tectônica rúptil, pelo intemperismo e pela evolução geomorfológica, permite o desenvolvimento de florestas de encosta do tipo higrófila (Projeto RS Biodiversidade, 2014). Nesses fragmentos florestais (Figs. 8B, 8C), de grande riqueza de espécies, as mais comuns são a canela-fedorenta (Nectandra megapotamica), o açoita-cavalo (Luhea divaricata), o angico (Parapiptadenia rigida), a canafístula (Peltophorum dubium) e o branquilho (Sebastiania commersoniana). Registra-se, também, a palmeira jerivá (Syagrus romanzoffiana), que em geral se destaca visualmente no dossel florestal. Ainda caracterizam essas florestas as samambaias e as epífitas, especialmente bromeliáceas do gênero Tillandsia (Projeto RS Biodiversidade, 2014).

A presença dos ambientes florestais nos geossítios da Serra do Segredo e das Pedras das Guaritas, condicionados pelos aspectos da geodiversidade, também são importantes por fornecerem o habitat para espécies da fauna nativa associadas a tais ambientes. Na Serra do Segredo foi identificada a presença de espécies de aves típicas de florestas como o inanbuguaçu (Crypturellus obsoletus), o surucuá-variado (Trogon surrucura) e o arapaçu-verde (Sittasomus griseicapilus) (Projeto RS Biodiversidade, 2014).

\subsection{Seixos "rolados" e diversidade de líquenes}

Um aspecto interessante dos geossítios Serra do Segredo e Pedras das Guaritas diz respeito à composição granulométrica de ambas as sucessões sedimentares. A litologia dominante, em ambos os geossítios, são arenitos conglomeráticos e conglomerados mal selecionados, nos quais os fragmentos maiores são do tamanho seixo a bloco. Na Serra do Segredo, esses blocos são subangulosos a subarredondados, de xistos básicos, anfibolitos, riolitos e granitoides de composição variada. Enquanto isso, nas Pedras das Guaritas, os blocos são geralmente muito arredondados e compostos por granitos e quartzo leitoso. Essa característica textural das rochas, que é resultado do tipo de sistema fluvial existente na região durante o início do Paleozoico, bem como da carga sedimentar dis- 


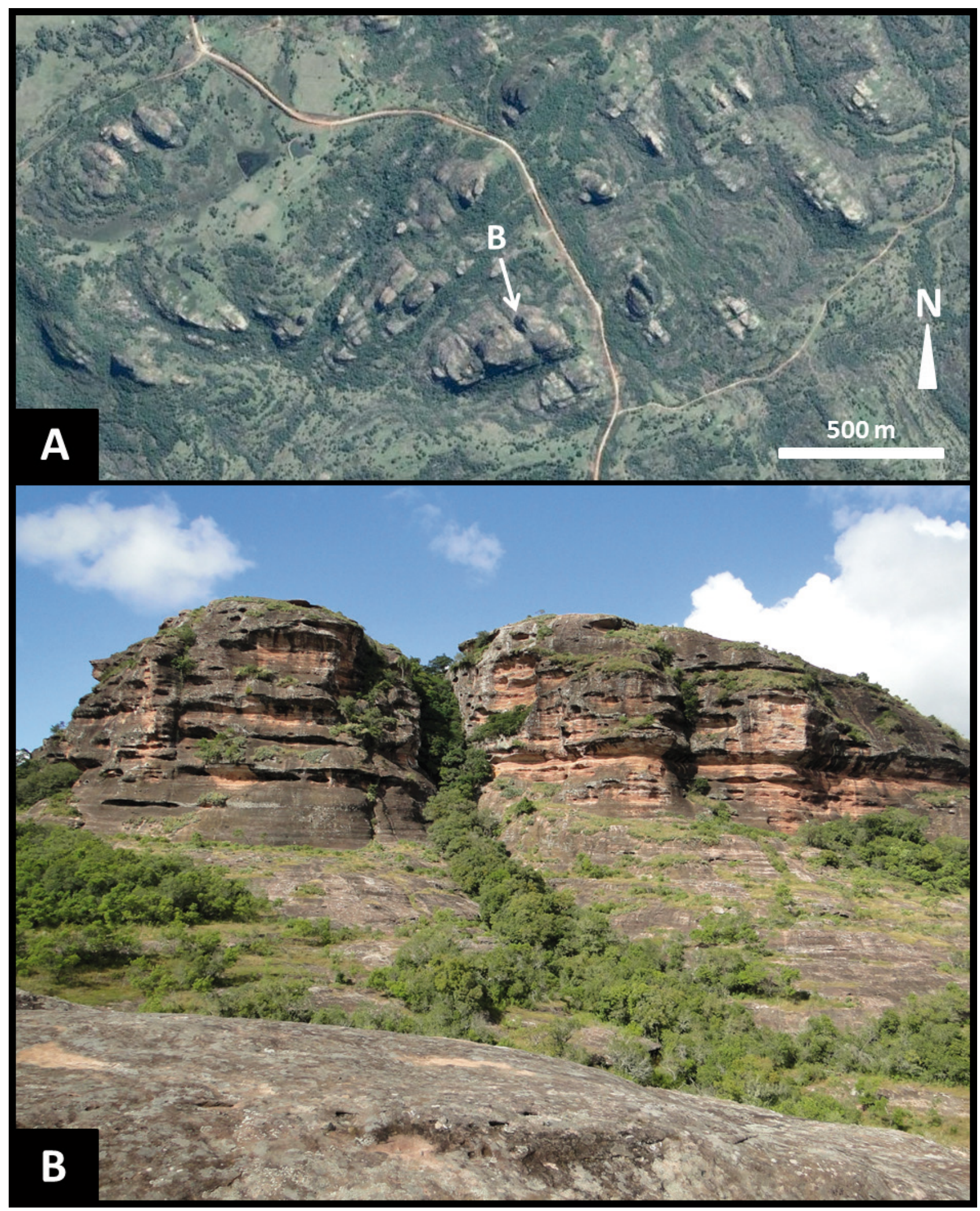

Figura 7. Relação entre estruturas da tectônica rúptil (direções NW-SE e NE-SW) e vegetação mais densa (arbustiva ou florestal) no geossítio Pedras das Guaritas, tanto em imagem de satélite (A) quanto no campo, em fotografia obtida desde o terreno da Associação dos Moradores das Guaritas (B); a posição da fotografia B está indicada na imagem A. 


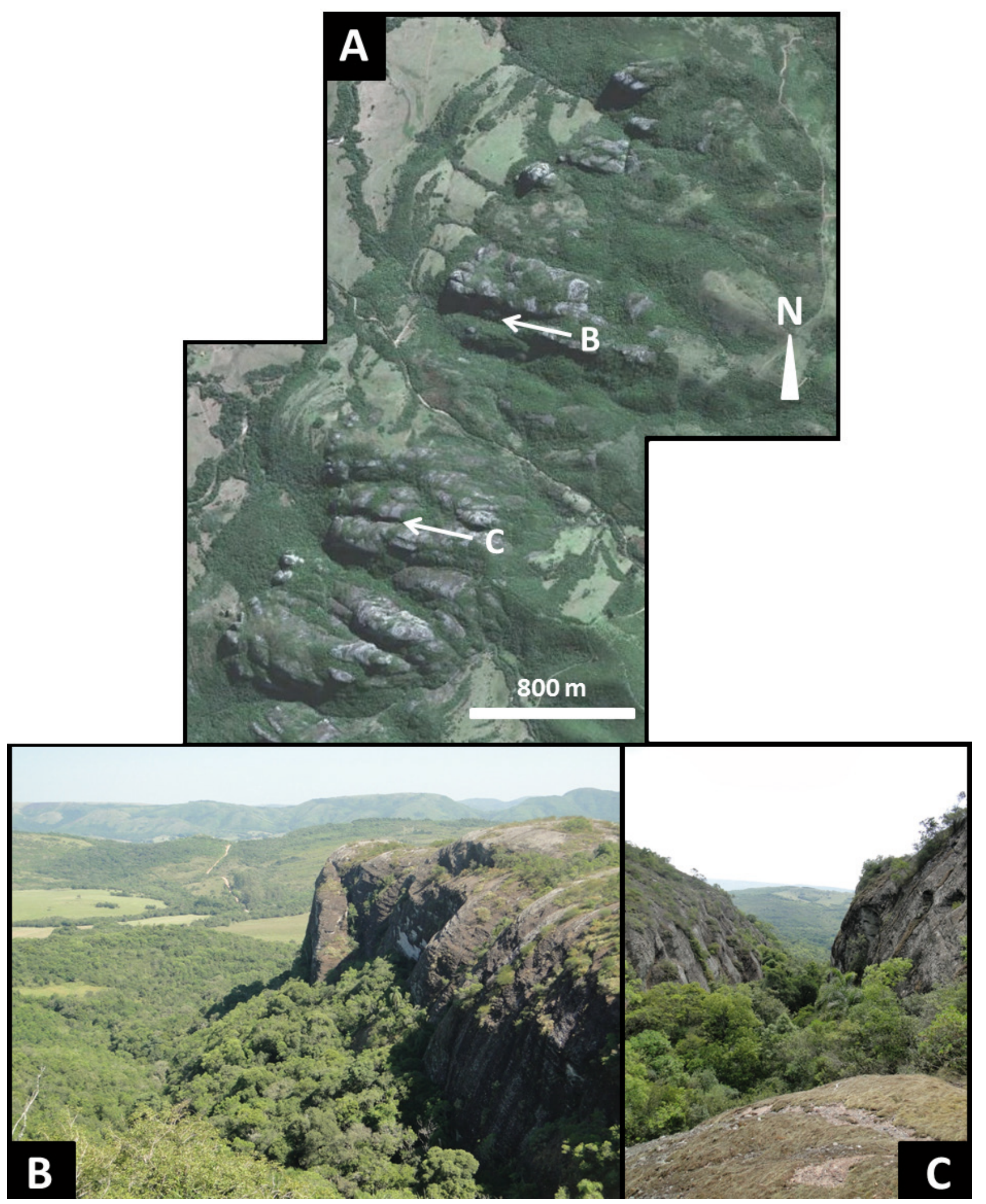

Figura 8. Relação entre estruturas da tectônica rúptil, principalmente na direção $\mathrm{N} 60^{\circ} \mathrm{W}$, e a presença de florestas na região da Serra do Segredo. A) Imagem de satélite da Serra do Segredo, indicando a posição das fotografias B e C; B) Floresta higrófila de encosta na face sul da geoforma "Pedra do Segredo"; C) Floresta higrófila na porção sul da Serra do Segredo, no local chamado "Vallecito". 
ponível nos altos estruturais adjacentes à época, é fundamental para a diversidade de líquenes verificada naquelas áreas.

As porções de rocha nua do geossítio Pedras das Guaritas, desde patamares quase horizontais até paredes verticalizadas, são ocupadas principalmente por líquenes crustosos e foliosos de cor branca a cinzenta. Tais líquenes dominam as porções homogêneas de arenito, especialmente em locais mais secos, com incidência de luz solar. No entanto, nessas mesmas áreas abertas, a existência de fragmentos arredondados (seixos e blocos "rolados" dos antigos rios que ali cruzaram) provê as condições para o crescimento de outra espécie de líquen, que ocorre prioritariamente sobre tais fragmentos: um líquen fruticoso (aspecto arbustivo ou arborescente), de cor verde-clara, possivelmente pertencente ao gênero Usnea sp. Essa relação está ilustrada na figura 9A. Além disso, alguns fragmentos mais angulosos de quartzo leitoso (quartzo de falha) apresentam-se recobertos por outro tipo de líquen crustoso, de coloração verde mais escura e aspecto brilhoso.

No geossítio Serra do Segredo, além de se verificar também a associação descrita acima nas paredes e patamares de maior insolação, é importante registrar a significativa cobertura das rochas por musgos (Bryophyta), o que provavelmente se relaciona com a maior umidade e sombreamento nas faces e vertentes voltadas para sul. Nesse caso, com os musgos formando verdadeiros "tapetes verdes" sobre as porções arenosas das rochas, os fragmentos no tamanho bloco são os únicos refúgios encontrados por diversos tipos de líquenes para se desenvolverem: líquenes crustosos brancos, cinzentos e alaranjados (estes últimos, possivelmente do gênero Caloplaca sp.), líquenes foliosos brancos e, por fim, líquenes fruticosos de cor verde-clara (Figs. 9B, 9C). Dessa forma, demonstra-se a importância da presença dos fragmentos de grande diâmetro na provisão das condições de substrato para o desenvolvimento desses líquenes. Essas comunidades de líquenes e sua associação com as rochas em que se sustentam são pouco conhecidas, merecendo mais atenção da comunidade científica.

\subsection{Cavidades do tipo tafoni como refúgios de fauna e flora}

Ambas as regiões analisadas possuem inúmeras paredes afetadas por cavidades do tipo tafoni e honeycomb (alvéolos). Cavidades do tipo tafoni, segundo revisão realizada por Paradise (2013), formam-se por intemperismo químico (ação da umi- dade e da infiltração da água) a partir de alguma suscetibilidade intrínseca da rocha afetada, e sua ocorrência ainda é influenciada pela ação do vento e/ou da insolação. No caso das rochas dos geossítios Serra do Segredo e Pedras das Guaritas, essa suscetibilidade é verificada: (a) na presença de fragmentos arredondados tamanho bloco em meio à matriz arenosa, onde a cimentação junto ao fragmento nunca terá a mesma coesão da matriz; (b) nos contatos entre as diferentes camadas; (c) na presença de camadas de diferente granulometria, compactação, grau de cimentação ou composição diagenética; e, (d) na presença de fraturas e falhas que cortam os maciços de rocha sã. Além disso, a evolução geomorfológica de ambos os geossítios se processou sob a influência de profundas mudanças climáticas de caráter cíclico. 0 clima, nesta parte do continente, já registrou períodos muito mais quentes e úmidos (períodos interglaciais) e, por outro lado, experimentou fases mais frias e secas, com ventos fortes e eventualmente carregados de poeira, dotados de algum poder abrasivo e, sobretudo, erosivo. A importância relativa desses fatores na formação de cavidades tipo tafoni na região de Caçapava do Sul ainda não foi objeto de estudos específicos.

Para o presente trabalho, importa destacar exemplos do quanto essas cavidades são decisivas para a estruturação de habitat para espécies da flora e fauna. Tafoni jovens ou pouco desenvolvidos, incipientes, circulares, de pequeno diâmetro e profundidade, são utilizados como "substrato" para colmeias de marimbondos (Fig. 10A). Quando o processo de desgaste avança um pouco, essas cavidades são eleitas como refúgio ou local de nidificação para diferentes espécies de aves. Com base em trabalhos anteriores e uma preocupação voltada ao impacto da escalada em rocha, Ribeiro et al. (2009) elaboraram uma lista de espécies de aves que frequentam paredes rochosas no sul e sudeste do Brasil. Algumas dessas espécies são frequentemente avistadas na Serra do Segredo, fazendo parte da lista divulgada pelo Projeto RS Biodiversidade (2014). Entre as espécies locais que, comprovadamente, utilizam cavidades em paredões rochosos para nidificação e reprodução, estão: (a) o urubu-de-cabeça-preta (Coragyps atratus), da família Cathartidae; (b) a pomba-de-bando (Zenaida auriculata), da família Columbidae; e ainda (c) a maria-preta-de-penacho (Knipolegus lophotes) e o birro (Hirundinea ferruginea), ambos da família Tyrannidae. A utilização dos tafoni das paredes rochosas da Serra do Segredo por aves é atestada pelos excrementos que escorrem de algumas cavidades, tingindo as paredes de branco (Fig. 

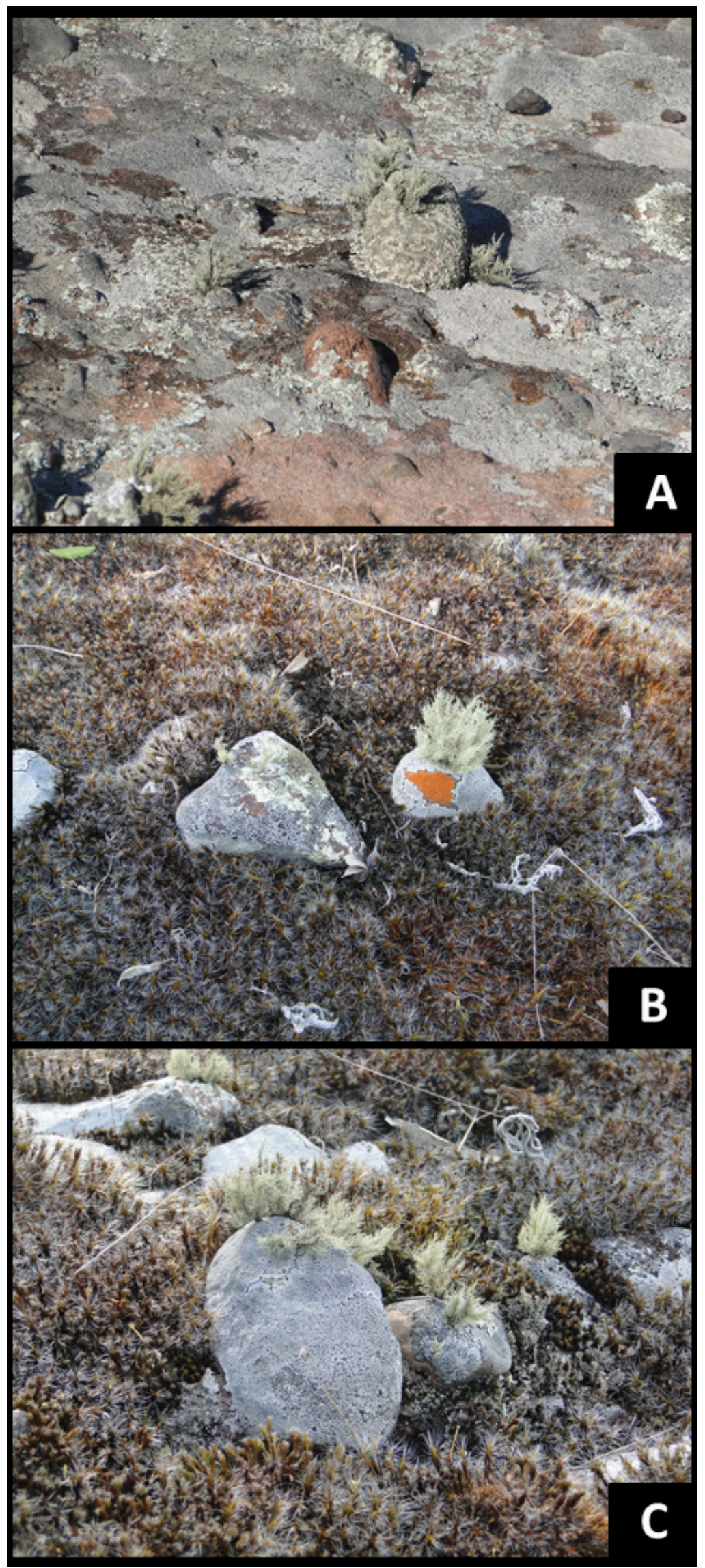

Figura 9. Fragmentos arredondados tamanho bloco, destacados em relação à matriz de granulometria areia grossa ou grânulos, e sua influência na distribuição e na diversidade de líquenes. (A) Em áreas com insolação, a porção da matriz é recoberta por líquenes crostosos e foliosos, enquanto os líquenes fruticosos ocorrem apenas nos clastos de maior diâmetro; (B, C) Em áreas sombreadas e úmidas, as porções mais homogêneas recebem a cobertura de um tapete de musgos, e os blocos maiores acabam constituindo os refúgios para os líquenes crostosos e fruticosos. 
10B). As espécies maria-preta-de-penacho e birro foram inclusive reconhecidas e fotografadas (Figs. 10C, 10D) pelos autores deste trabalho em saída a campo realizada em 19/3/2015, nos galhos de uma árvore seca em frente à geoforma "Pedra da Abelha", região norte da Serra do Segredo.

Outras feições do tipo tafoni, mais evoluídas, ainda mais amplas e circulares, posicionadas na face oeste da geoforma chamada "Pedra do Segredo", constituem o refúgio de vegetais dos gêneros Dickia sp. (Bromeliaceae) e Cereus sp. (Cactaceae), entre outros (Fig. 11A). Enquanto isso, nas faces mais sombreadas das Pedras das Guaritas, essas cavidades mais desenvolvidas e profundas abrigam samambaias, colmeias de marimbondos, aracnídeos e outros organismos (Fig. 11B). Ambas as regiões também possuem tafoni amalgamados, produzidos pelo progressivo avanço do intemperismo, retirada de material pelo vento e colapso dos tetos e das paredes das cavidades (Paradise,
2013). Essas porções amalgamadas, conjugadas, na Serra do Segredo, com o leve basculamento das camadas, formam verdadeiros "degraus" nos cerros (Figs. 4B, 4C). Alguns desses patamares, que retêm material solto e chegam a formar solos muito delgados, abrigam uma vegetação bastante diversificada, onde se destacam as palmeiras do tipo jerivá (Syagrus romanzoffiana, Arecaceae). A face sudoeste da "Pedra da Abelha" possui um desses patamares inclinados segundo a atitude das camadas, dando a impressão de que as palmeiras, em fila, "sobem" o cerro em direção a seu topo (Fig. 11C). Já na região das Pedras das Guaritas, além do jerivá, também ocorre outra palmeira, a Trithrinax brasiliensis (carandaí ou buriti), a qual se distingue pela folha flabeliforme (em forma de leque) e encontra-se criticamente ameaçada de extinção no Rio Grande do Sul (Lista da Flora Ameaçada de Extinção do RS Decreto Estadual no 52.109/2014).

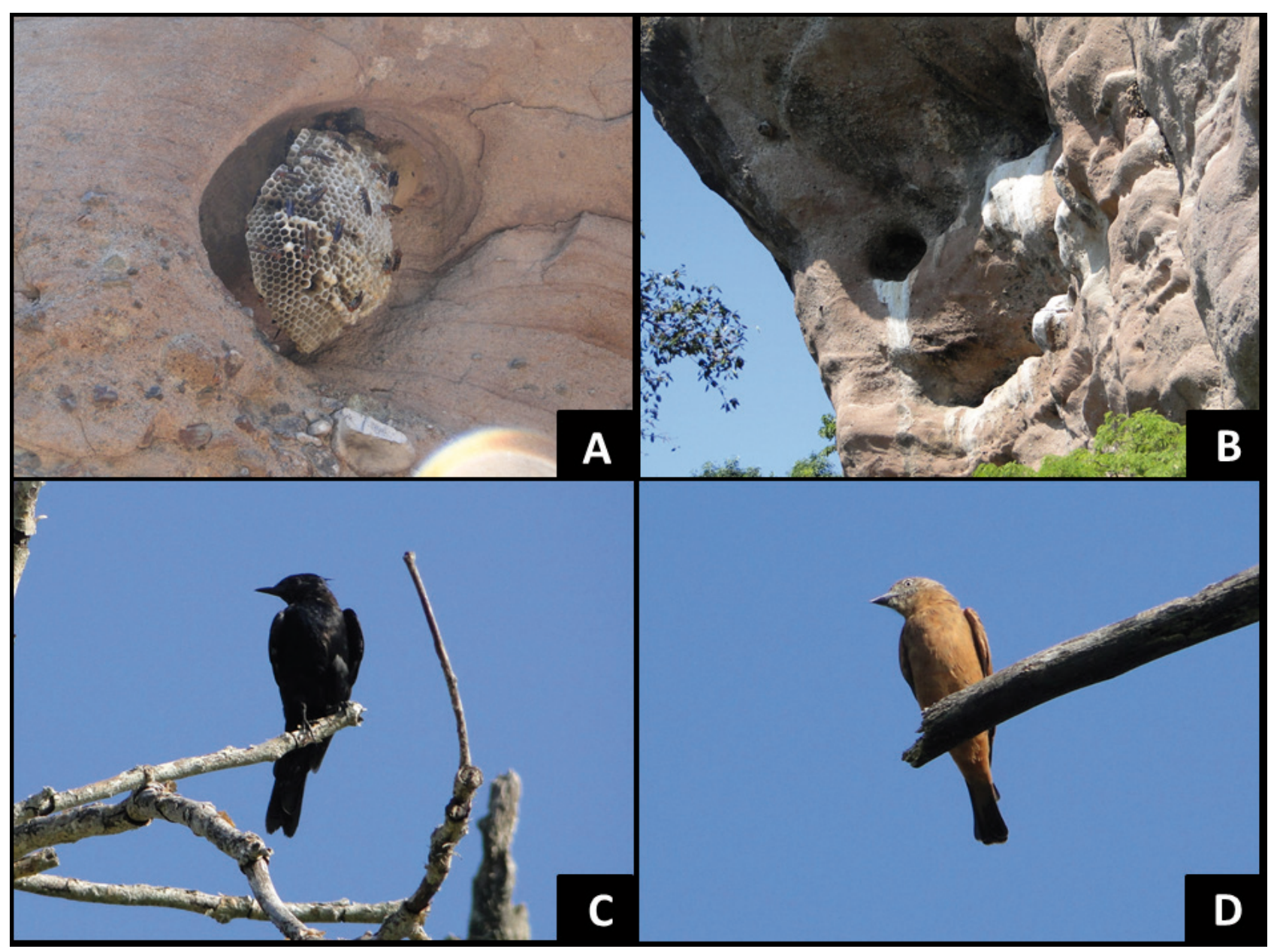

Figura 10. Cavidades do tipo tafoni e estruturação de habitat. A) Cavidade incipiente, pequena e ainda sem significativo aprofundamento, servindo para a implantação de uma colmeia de marimbondos; B) Manchas brancas dos excrementos de aves na entrada de tafoni em uma parede (face oeste) da "Pedra da Abelha", demonstrando a utilização dessas feições pela avifauna; C) Maria-preta-de-penacho (Knipolegus lophotes); D) Birro (Hirundinea ferruginea). As aves ilustradas em (C) e (D) são conhecidas por utilizarem cavidades em paredões rochosos, fotografadas no geossítio Serra do Segredo. 


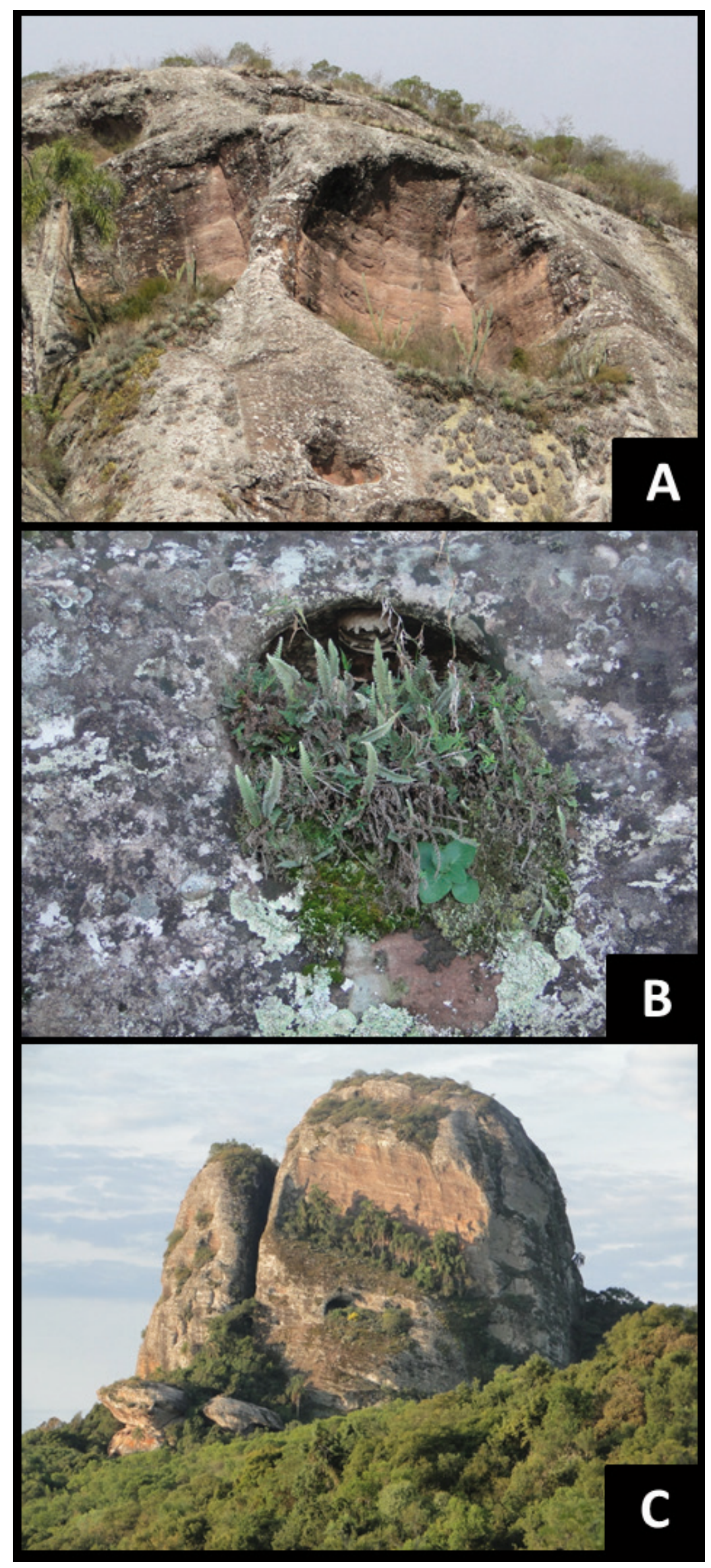

Figura 11. Em seus estágios mais avançados, os tafoni chegam a desenvolver delgadas camadas de solo, e abrigam vegetação. A) Bromeliáceas e cactáceas em cavidade na "Pedra do Segredo"; B) Samambaias e uma colmeia de marimbondos no interior de uma cavidade nas Pedras das Guaritas; C) Tafoni amalgamados, já transformados em degraus, com palmeiras jerivá (Syagrus romanzoffiana) em destaque, na "Pedra da Abelha", porção norte da Serra do Segredo. 


\subsection{Cavernas, blocos colapsados e fauna}

A base da principal geoforma da Serra do Segredo, a "Pedra do Segredo", possui uma caverna denominada "gruta da escuridão", com cerca de $60 \mathrm{~m}$ de extensão e orientada aproximadamente a N-S. Supõe-se que seja o resultado de intemperismo químico de rochas sedimentares argilosas posicionadas na base da sucessão de camadas fluviais da sequência III da Formação Santa Bárbara (Borba, 2001; Borba \& Mizusaki, 2003). Essa caverna é o habitat permanente de alguns insetos e aracnídeos, e pode servir de abrigo também para mamíferos cavernícolas, especialmente morcegos. Em uma lista da fauna registrada para a "Pedra do Segredo" (Projeto RS Biodiversidade, 2014), há alguns quirópteros que dependem desse tipo de feição geomorfológica para algumas atividades de seu ciclo de vida. Alguns deles são classificados como "cavernícolas oportunistas", que só utilizam as cavidades esporadicamente, como o morcego-vampiro (Desmodus rotundus) e outros morcegos da família Phyllostomidae (Glossophaga soricina, Platyrrhinus lineatus e Sturnira lilium), além do morcego Myotis riparius (Vespertilionidae). Enquanto isso, o morcego-falso-vampiro (Chrotopterus auritus, Phyllostomidae) é classificado como "essencialmente cavernícola" (e.g. Guimarães, 2014) e também foi registrado na Serra do Segredo.

Outro tipo de refúgio é proporcionado, na Serra do Segredo, por processos de colapso de blocos de rocha (Fig. 12A) que se desprenderam das paredes dos cerros em algum momento da evolução geomorfológica recente. Nas Pedras das Guaritas, onde há intercalações de arenitos com siltitos e/ou raros argilitos, essas rochas mais finas e mais ricas em micas e argilominerais se alteram mais facilmente, dando origem também a cavidades de grande extensão lateral, de espessura decimétrica, entre as camadas mais resistentes. Formadas através desses dois tipos de processos, essas "tocas" servem como abrigo para mamíferos como o furão-pequeno (Galictis cuja, Mustelidae, fig. 12B) registrado na área das Pedras das Guaritas, assim como para roedores e marsupiais. A presença dessas camadas de rochas mais argilosas também favorece a formação, ainda que incipiente, de mantos de intemperismo e solos (em geral, neossolos litólicos), o que proporciona também o substrato para organismos escavadores, como os tatus do gênero Dasypus sp. (Dasypodidae), muito comuns nas duas áreas.

Todos os tipos de cavidades existentes em ambos os geossítios constituem, igualmente, abri- gos potenciais para os mamíferos de médio porte (Canidae e Felidae) registrados naquelas áreas. Constam na lista de mamíferos os canídeos graxaim-do-campo (Lycalopex gymnocercus) e o graxaim-do-mato (Cerdocyon thous), os quais, além de outros tipos de esconderijos, utilizam também abrigos em fendas existentes nas rochas. Também usam esconderijos em grutas ou fendas nas rochas (Silva, 1984; Cimardi, 1996) os felinos jaguatirica (Leopardus pardalis), gato-maracajá (Leopardus wiedii) e jaguarundi ou gato-mourisco (Puma yagouaroundi), todos registrados nos dois geossítios (Konrad \& Paloski, 2000; Projeto RS Biodiversidade, 2014). Nas Pedras das Guaritas, Konrad \& Paloski (2000) citam também a presença remanescente de Puma concolor (puma, onça-parda ou leão-baio), que utiliza cavernas, tocas ou fendas em rochas como abrigo e também procura esses refúgios durante o período reprodutivo, para proteger seus filhotes (Silva, 1984; Cimardi, 1996).

\subsection{Marmitas, águas, anfíbios e peixes}

Por fim, outro importante elemento da geodiversidade dos dois geossítios focalizados são as estruturas relacionadas ao escoamento da água, especialmente quando se considera que: (a) a Serra do Segredo constitui uma importantíssima área de nascentes para o arroio dos Lanceiros, afluente do arroio Santa Bárbara e componente da bacia hidrográfica do rio Vacacaí; e (b) as Pedras das Guaritas representam área de nascentes e divisor de águas entre as microbacias dos arroios Passo dos Negros e João Dias, dois importantes afluentes da margem esquerda do rio Camaquã. Tendo em vista que, em ambas as áreas, o predomínio é de rochas muito pouco permeáveis (arenitos muito cimentados ou siltitos/argilitos), o destino da maior parte da precipitação pluviométrica é o escoamento superficial, o qual aproveita também os lineamentos tectônicos como áreas preferenciais, levando a um arranjo de cursos d'água encaixados em estruturas.

As feições de intemperismo chamadas de panelas ou marmitas (weathering pits, pans, gnammas), cujos processos de formação já foram revisados acima, ocorrem principalmente nos trechos iniciais dos cursos d'água, especialmente na região de nascentes do arroio Passo dos Negros, nas Pedras das Guaritas. É exatamente nessas áreas que se encontram as maiores populações de anfíbios (Konrad \& Paloski, 2000). Durante as saídas a campo realizadas para este trabalho, em pelo menos uma oportunidade, em 10 de novembro de 2014, com significativo fluxo de água, foi constatada a 


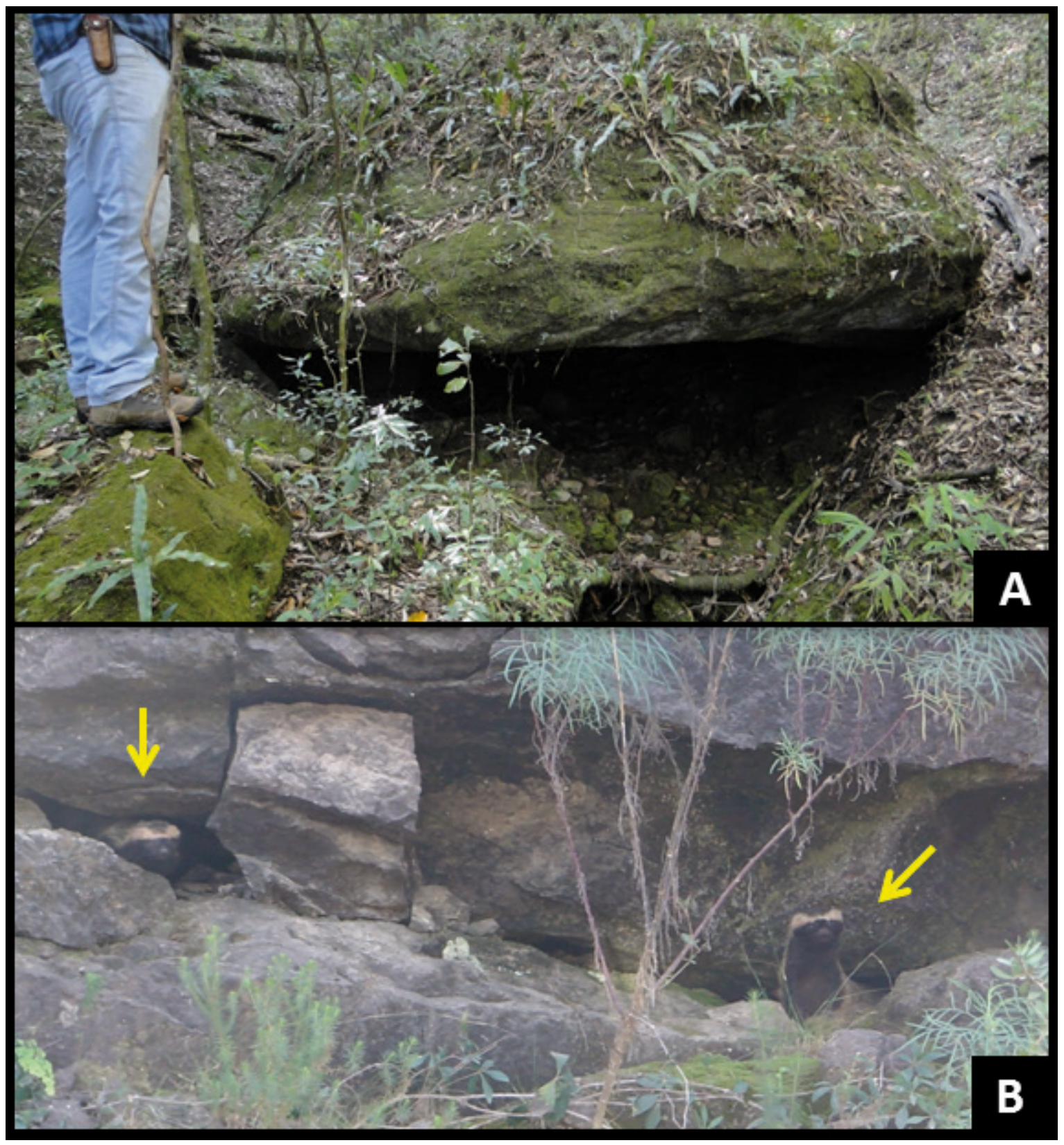

Figura 12. Relação entre cavidades e abrigos para a fauna. A) Abrigo formado pelo colapso (abatimento) de blocos de rocha e pelo intemperismo diferencial na base da geoforma "Pedra do Segredo", onde podem se refugiar diversos mamíferos de pequeno a médio porte; B) Cavidade alongada, de espessura/altura decimétrica, formada pela alteração preferencial de argilitos/ siltitos, na área das Pedras das Guaritas, com dois espécimes de furão-pequeno (Galictis cuja, Mustelidae).

utilização de algumas marmitas de menor profundidade para a reprodução de anfíbios, pois essas feições se encontravam repletas de girinos (Figs. 13A, 13B). O arroio Passo dos Negros também aproveita fraturas de direção N-S e NE-SW (Fig. 13C) para o fluxo da água e, nas bordas dessas fraturas, em porções relativamente mais sombreadas, se desenvolvem diversos tipos de musgos. Em termos de peixes, uma pesquisa realizada no arroio João Dias, imediatamente a leste do arroio Passo dos Negros, demonstrou grande diversidade, com 36 espécies, divididas entre Siluriformes (jundiás, violas e cascudos, com 44,44\%), Characiformes
(36,11\%, sobretudo traíras e lambaris) e Perciformes $(11,11 \%$, representados pelos carás). Essa relativa abundância de água superficial, confinada aos vales encaixados em estruturas tectônicas, e de espécies de peixes, favorece também o registro, tanto no geossítio Pedras das Guaritas (Konrad \& Paloski, 2000) quanto no geossítio Serra do Segredo (Projeto RS Biodiversidade, 2014), de aves da família Alcedinidae (as diferentes espécies de martim-pescador, dos gêneros Ceryle sp. e Chloroceryle sp.). 


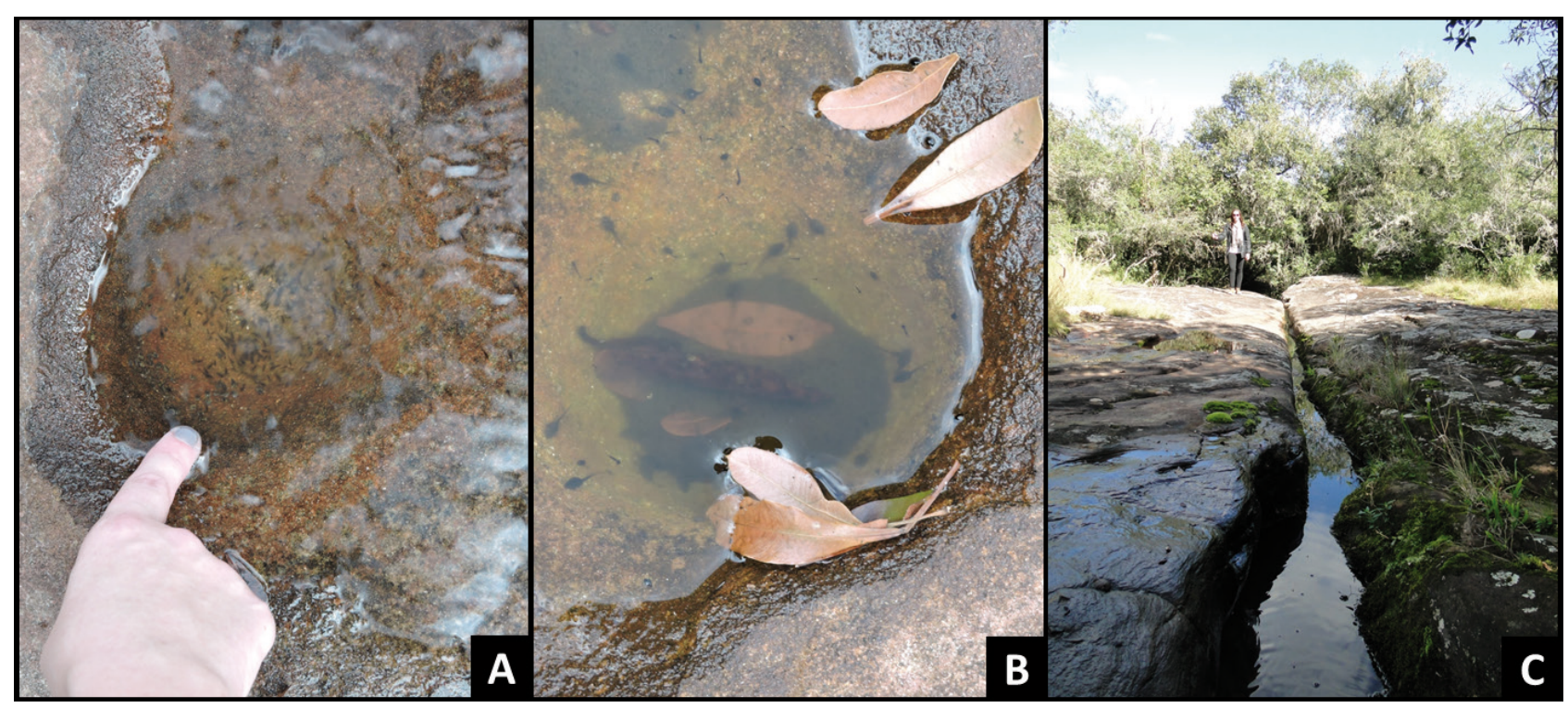

Figura 13. Aspectos relacionados à região de nascentes do arroio Passo dos Negros, no geossítio Pedras das Guaritas. A, B) Marmitas com substancial fluxo de água e presença marcante de formas jovens (girinos) de anfíbios; C) A água do arroio segue fraturas de direção NNE-SSW, em cujas margens se desenvolvem diversos tipos de musgos (Bryophyta).

\section{Conclusões}

As informações aqui apresentadas demonstram o quanto a geodiversidade intrínseca dos geossítios, resultado de uma conjunção de processos de gênese, deformação e alteração de rochas, influencia na estruturação de diferentes habitat e, consequentemente, na biodiversidade local. Os geossítios analisados, a Serra do Segredo e as Pedras das Guaritas, em Caçapava do Sul, no centro-sul gaúcho, formados por rochas sedimentares antigas e muito litificadas, destacam-se no relevo e na paisagem por causa de sua significativa impermeabilidade e consequente resistência ao intemperismo. Os processos deposicionais, deformacionais e de alteração intempérica produziram uma série de feições geológicas e geomorfológicas que, na escala do geossítio, constituem a sua geodiversidade intrínseca. Essa diversidade de feições permitiu o estabelecimento, a estruturação e a manutenção de diferentes habitat e abrigos para distintos organismos em diversas fases de seus ciclos de vida. Dos líquenes às florestas higrófilas de encosta, passando pelas cactáceas, bromeliáceas e palmeiras, toda a vegetação das duas áreas é influenciada, condicionada ou mesmo determinada pelas feições da geodiversidade. Assim também funciona com relação à fauna: os morcegos utilizam as cavernas produzidas pelo intemperismo químico, assim como fazem eventualmente mustelídeos, canídeos e felinos; os marimbondos constroem suas colmeias sob a proteção das feições do tipo tafoni, que também abrigam aves em nidificação; anfíbios aproveitam marmitas de dissolução para sua re- produção; e as águas, que escoam pela superfície impermeável apenas onde permitem as fraturas, viabilizam a diversidade dos peixes e o alimento do martim-pescador. A conclusão de que a geodiversidade, produzida pela evolução geológica, condiciona a biodiversidade não significa que aquela seja mais importante do que esta; muito antes, demonstra que a natureza é a união indissociável entre geodiversidade e biodiversidade, em um sistema naturalmente dinâmico ao longo do tempo. Portanto, a conservação da natureza deve levar em conta também a estrutura física dos habitat, dos ecossistemas e dos biomas, para que seus resultados possam ser mais efetivos e equilibrados. Ambos os geossítios analisados, por todas as características de geodiversidade e biodiversidade, merecem iniciativas de conservação urgentes e abrangentes.

Agradecimentos - Os autores agradecem a cuidadosa revisão efetuada por Ricardo Fraga e Marcos Nascimento, bem como o trabalho de edição realizado por Ana Maria Pimentel Mizusaki, Maria do Carmo Lima e Cunha e Paulo Alves de Souza, de Pesquisas em Geociências. Agradecem também a todos os colegas do Grupo de Pesquisa PANGEA (Patrimônio Natural, Geoconservação e Gestão da Água), da Universidade Federal de Santa Maria, pela companhia em diversas saídas a campo.

\section{Referências}

Almeida, F.F.M. 1969. Diferenciação Tectônica da Plataforma Brasileira. In: CONGRESSO BRASILEIRO DE GEOLOGIA, 23, Salvador, 1969. Anais..., Salvador, p. 29-46. 
Borba, A.W. 2001. Formação Santa Bárbara (Eo-paleozóico da região de Caçapava do Sul): uma nova visão através de técnicas estratigráficas e geocronológicas. Porto Alegre, 131p. Dissertação de Mestrado, Programa de Pós-graduação em Geociências, Instituto de Geociências, Universidade Federal do Rio Grande do Sul.

Borba, A.W. 2006. Evolução geológica da "Bacia do Camaquã" (Neoproterozóico e Paleozóico inferior do Escudo Sul-rio-grandense, RS, Brasil): uma visão com base na integração de ferramentas de estratigrafia, petrografia e geologia isotópica. Porto Alegre, $110 \mathrm{p}$. Tese de Doutorado, Programa de Pós-graduação em Geociências, Instituto de Geociências, Universidade Federal do Rio Grande do Sul.

Borba, A.W. 2011. Geodiversidade e geopatrimônio como bases para estratégias de geoconservação: conceitos, abordagens, métodos de avaliação e aplicabilidade no contexto do Estado do Rio Grande do Sul. Pesquisas em Geociências, 38(1): 3-13.

Borba, A.W. \& Mizusaki, A.M.P. 2003. Santa Bárbara Formation (Caçapava do Sul, Southern Brazil): depositional sequences and evolution of an Early Paleozoic post-collisional basin. Journal of South American Earth Sciences, 16: 365-380.

Borba, A.W., Vignol-Lelarge, M.L.M. \& Mizusaki, A.M.P. 2002. Uplift and denudation of the Caçapava do Sulgranitoids (Southern Brazil) during Late Paleozoic and Mesozoic: constraints from apatite fission-track data. Journal of South American Earth Sciences, 15: 683-692.

Borba, A.W., Mizusaki, A.M.P., Silva, D.R.A. \& Kawashita, K. 2003. Razões isotópicas ${ }^{87} \mathrm{Rb} /{ }^{86} \mathrm{Sr},{ }^{87} \mathrm{Sr} /{ }^{86} \mathrm{Sr}$ e ${ }^{143} \mathrm{Nd} /{ }^{144} \mathrm{Nd}$ como traçadores de proveniência de rochas sedimentares siliciclásticas: exemplos no Grupo Camaquã (Paleozóico inferior, RS, Brasil). Pesquisas em Geociências, 30(2): 39-50.

Borba, A.W., Souza, L.F., Mizusaki, A.M.P., Almeida, D.P.M. \& Stumpf, P.P. 2013. Inventário e avaliação quantitativa de geossítios: exemplo de aplicação ao patrimônio geológico do município de Caçapava do Sul (RS, Brasil). Pesquisas em Geociências, 40(3): 275-294.

Brilha, J.B.R. 2005. Património geológico e geoconservação. Viseu, Palimage Editores, 190p.

Brilha, J.B.R. 2015. Inventory and quantitative assessment of geosites and geodiversity sites: a review. Geoheritage, Review Articles, Online First: 1-16, DOI 10.1007/s12371-014-0139-3.

Cimardi, A.V. 1996. Mamíferos de Santa Catarina. Florianópolis, FATMA, 302p.

Dadalt, L. P. 2010. Padrões de diversidade da vegetação lenhosa da região do Alto Camaquã, Rio Grande do Sul, Brasil. Porto Alegre, 56p. Dissertação de Mestrado, Programa de Pós-graduação em Ecologia, Instituto de Biociências, Universidade Federal do Rio Grande do Sul.

De Ros, L.F., Morad, S. \& Paim, P.S.G. 1994. The role of detrital composition and climate on the diagenetic evolution of continental molasses: evidence from the Cambro-Ordovician Guaritas Sequence, southern Brazil. Sedimentary Geology, 92: 197-228.
Fassoulas, C., Mouriki, D., Dimitriou-Nikolakis, P. \& Iliopoulos, G. 2012. Quantitative assessment of geotopes as an effective tool for geoheritage management. Geoheritage, 4(3): 177-193.

Fragoso-Servón, P., Pereira, A., Faustro, 0. \& Bautista, F. 2014. Relación entre la geodiversidad de Quintana-Roo y su biodiversidad. Quivera, 16(1): 97-125.

Fuertes-Gutiérrez, I. \& Fernández-Martínez, E. 2010. Geosites inventory in the Leon Province (Northwestern Spain): a tool to introduce geoheritage into regional environmental management. Geoheritage, 2: 57-75.

García-Cortés, A. \& Carcavilla-Urquí, L. 2009. Documento metodológico para la elaboración del inventario Español de lugares de interes geológico. Instituto Geológico y Minero de España, IGME, 61p.

Gordon, J.E. \& Barron, H.F. 2013.The role of geodiversity in delivering ecosystem services and benefits in Scotland. Scottish Journal of Geology, 49: 41-58.

Gray, M. 2004. Geodiversity: valuing and conserving abiotic nature. Chichester, Wiley, 448p.

Guadagnin, D.L., Larocca, J. \& Sobral, M. 2000. Flora vascular de interesse para a conservação na bacia do arroio João Dias: Avaliação Ecológica Rápida. In: Ronchi, L.H. \& Lobato, A.O.C. (Eds.) Minas do Camaquã: um estudo multidisciplinar. São Leopoldo, Editora UNISINOS, p. 72-84.

Guimarães, M.M. 2014. Morcegos cavernícolas do Brasil: composição, distribuição e serviços ambientais. Lavras, 130p. Dissertação de Mestrado, Programa de Pós-graduação em Ecologia Aplicada, Universidade Federal de Lavras.

Jacková, K. \& Romportl, D. 2008. The relationship between geodiversity and habitat richness in Sumava National Park and Krivoklatsko PLA (Czech Republic): a quantitative analysis approach. Journal of Landscape Ecology, 1(1): 23-38.

Konrad, H.G. \& Paloski, N.I. 2000. Fauna da região das Minas do Camaquã, sub-bacia do arroio João Dias. In: Ronchi, L.H. \& Lobato, A.O.C. (Eds.) Minas do Camaquã: um estudo multidisciplinar. São Leopoldo, Editora UNISINOS, p. 85-108.

McBride, E.F. \& Picard, M.D. 2000. Origin and development of tafoni in Tunnel Spring Tuff (Oligocene), Crystal Peak, Utah. Earth Surface Processes and Landforms, 25: 869-879.

Mohammad, M.K. \& Al-Zubaidi, A.A. 2014. Potentials of geodiversity for biodiversity at Ga'ara Depression, Iraqi Western Desert. Advances in Bioresearch, 5(1): 169-177.

Mustoe, G.E. 1982. The origin of honeycomb weathering. Geological Society of America Bulletin, 93: 108115.

Paim, P.S.G., Chemale Jr., F. \& Lopes, R.C. 2000. A Bacia do Camaquã. In: Holz, M. \& De Ros, L.F. (Eds.) Geologia do Rio Grande do Sul, Porto Alegre, Edições CIGO/ UFRGS, p. 231-274.

Paim, P.S.G., Fallgater, C. \& Silveira, A.S. 2010. Guaritas do Camaquã, RS: exuberante cenário com formações geológicas de grande interesse didático e turístico. In: Winge, M., Schobbenhaus, C., Souza, C.B.G., Fer- 
nandes, A.C.S., Berbert-Born, M., Sallun-Filho, W. \& Queiroz, E.T. (Eds.) Sítios geológicos e paleontológicos do Brasil. Disponível em <http://www.unb.br/ ig/sigep/sitio076/sitio076.pdf>. Acesso em: 28 mai. 2015.

Panizza, M. 2009. The geomorphodiversity of the Dolomites (Italy): a key to geoheritage assessment. Geoheritage, 1: 33-42.

Paradise T.R. 2013. Tafoni and other rock basins. In: John F. Shroder (Ed.) Treatise on Geomorphology. San Diego, Academic Press, 4, p. 111-126.

Projeto RS Biodiversidade 2014. Avaliação Ecológica Rápida (AER) Pedra do Segredo. ABG \& Projeto RS Biodiversidade, Porto Alegre, 212p. Disponível em dois arquivos PDF no link < http://www.biodiversidade.rs.gov.br/portal/index.php>. Acesso em: 28 mai. 2015.

Ribeiro, K.T., Lorenzetto, A. \& Rodrigues, C.G.O. 2009. Bases para manejo de escaladas em unidades de conservação. In: Seminário FEMESP de mínimo impacto do Baú 2009. Disponível em <http://www.femesp. org/docs/seminario2009_artigo_escaladas_uc.pdf>. Acesso em: 28 mai. 2015.

Man. 585.

Editores: Ana Maria P. Mizusaki \& Maria do Carmo Lima e Cunha.
Rodríguez-Navarro, C., Doehne, E. \& Sebastian, E. 1999. Origin of honeycomb weathering: role of salts and wind. Geological Society of America Bulletin, 111: 1250-1255.

Sharples, C. 1993. A methodology for the identification of significant landforms and geological sites for geoconservation purposes. Forestry Comission, Tasmania, 31p. (Internal Report).

Silva, F. 1984. Mamíferos silvestres: Rio Grande do Sul. Porto Alegre, Fundação Zoobotânica, 245p.

Souza, L.P.M. 2014. Trilhas geoturísticas para interpretação do geossítio Guaritas - Caçapava do Sul/RS. Santa Maria, 52p. Trabalho de Conclusão de Curso, Geografia-Licenciatura, Universidade Federal de Santa Maria.

Stanley, M. 2000. Geodiversity. Earth Heritage, 14: 1518.

Suertegaray, D.M.A. \& Silva, L.A.P. 2009. Tchê Pampa: histórias da natureza gaúcha. In: Pillar, V.P., Müller, S.C., Castilhos, Z.M.S. \& Jacques, A.V.A. (Eds.) Campos Sulinos: conservação e uso sustentável da biodiversidade. Brasília, Ministério do Meio Ambiente, p. 4259. 